\title{
Growth and Nutritional Indices of Oyster Mushroom (Pleurotus ostreatus) on Different Substrates
}

\author{
Sangeetha Menon ${ }^{1 *}$, Syeda Ayesha ${ }^{1}$, Pavithra $\mathrm{K}^{1}$ and Malsawmtluangi ${ }^{1}$ \\ 'Department of Life Sciences, Kristu Jayanti College (Autonomous), K. Narayanapura, Kothanur (PO), Bengaluru-560077 \\ ${ }^{*}$ Corresponding author: sangeethamenon@kristujayanti.com
}

\begin{abstract}
Lignocellulosic wastes such as agricultural wastes, forestry residues, grasses and woody materials represent huge amount of unutilized renewable resources and are generated every year throughout the world through agricultural practice, paper-pulp industries, timber industries and many agro-industries. The largest reservoir of fermentable carbohydrates is mostly wasted in the form of pre-harvest and post-harvest agricultural losses and wastes of food processing industries causing environmental pollution. Mushrooms are rich in protein, edible fiber and minerals but lipid content is low. Cultivation of mushrooms is a prime factor for the conversion of this low value inedible wastes into a higher value commodity which can serve as food material for humans and as a source of commercially important metabolites. Oyster mushroom is commercially important and is best known for its taste, flavour, high nutritional values and some medicinal properties. In the present study, Oyster mushrooms ( $P$. ostreatus) were grown on different substrates viz., Paddy straw, banana leaves and coconut coir. Growth and yield studies were undertaken and harvested mushrooms were also studied for their nutritional indices. Biological efficiency of the substrate was also determined. It was observed that all the three substrates were efficient as substrate for mushroom cultivation. Results of the present study also indicated that the studied mushrooms have good nutritive value for human although the nutritional content varied with each substrate.
\end{abstract}

Keywords: Lignocellulosic wastes, Oyster mushroom, Nutritional indices, Biological efficiency

\section{Introduction}

The growth of the population coupled with inadequate supply of food, diminishing quality of health, high rate of unemployment and increasing environmental degradation are some of the key underlying problems affecting the future well-being of humankind. The magnitude of these problems is said to increase as the world's population continues to grow (1). Mushroom cultivation can alleviate poverty and improve livelihoods through reliable source of income generation. Mushroom cultivation is a viable and attractive activity for rural farmers and peri-urban dwellers and reduces the need for large area of land amidst the growing population. Oyster mushroom belongs to the class Agaricomycetes, order Agaricales, family Pleurotaceae or Tricholomataceae, genus Pleurotus and species ostreatus. Scientifically, oyster mushroom is known as Pleurotus ostreatus. The Latin word Pleurotus means 'beside the ear' and ostreatus means 'oyster shaped' (2). Oyster mushrooms include many species such as $P$. flobellotus $P$. sojar - caju, $P$. eryngii, $P$. osfreafies, $P$. floride and $P$. sapidus (3). There are over 70 species of Pleurotus for which new species still being discovered (4). Oyster mushroom is an edible, saprophytic and lignocellulolytic type of mushroom. It has a pale lilac-grey spore print with a soft fleshy fruiting body rangeing in color from white to grey, brown or even blackish. The fruiting bodies of oyster mushroom are usually flat with the cap offset from the stalk, or the stalk hardly present at all. All the varieties or species of oyster mushrooms are edible except $P$. olearius and $P$. nidoformis (5). The caps of oyster mushrooms are shell shaped, semicircular to elongate. The margins are smooth and sometimes wavy and are whitish to grayish to tan; the texture is velvety, the flesh is thick and white, gills are narrow, the stalk is short, thick and white and the base being hairy. The spores look narrowly elliptical, smooth and colorless when magnified. On average, the cap width ranges between $2-15 \mathrm{~cm}$, stalk length is around $4 \mathrm{~cm}$ and stalk width is around $2 \mathrm{~cm}$. Pleurotus ostreatus predominantly grows on hardwoods such as stumps, logs, and trunks of deciduous trees (6).

The process for the cultivation of oyster mushroom is simple because its cultivation does not lend itself to complex scientific procedures. The cultivation of the fungi relies on the interaction of a particular set of physical, chemical and biological factors. The important areas to note in the cultivation of oyster mushroom in order to balance the three factors include substrate selection, composting, pasteurization, spawn running, fruiting and harvesting (7). Multi-lateral enzyme system in these mushrooms enables them to utilize variety of agricultural wastes. These agricultural wastes can be maize cob, rice straw, bean straw, coconut coir, sawdust etc. (8). One significant point about the agricultural wastes is that these agro-wastes are easy to come by and inexpensive to own. The oyster mushroom, being lignocellulotic in nature, has enzymes that have the ability to break down the lignin and the cellulose in the agro-waste to release 
nutrients for the developing mycelia. Lignocellulose consists of lignin, hemicelluloses and cellulose and large amounts of lignocellulose wastes are often disposed of by burning, particularly in developing countries (9). A range of about 200 different wastes is available as oyster mushroom substrates (10). For small scale farming there is the need for an effective substrate for the growth of mushroom, more especially Pleurotus ostreatus. The main substrate used for the production of this mushroom is sawdust. Coconut coir is a major waste in the coconut producing regions in the country such as the Western region. Its disposal is a big problem to the producers therefore to recycle the waste will be an innovative way of preventing environmental pollution. Meerow (11) reported that better growth index, top and root dry weights of crops in coir based medium than sedge peat-based medium. Since mushrooms can grow on a wide variety of agro-waste materials because of their ability to convert these less useful products into a high quality protein, it naturally opens new job opportunities especially in rural areas where the standard of living is very low (12). Low income earners can start this job with very little capital since all these agro wastes can be taken free of charge from the farms. The whole production process of oyster mushroom takes about 42 days and this is less than the life cycle of most arable crops (13). It is therefore an early income generating business that can give rapid income to the family. The farmers normally burn the wastes with the smoke being environmental nuisance. The biomass of these crops can be enhanced when used in mushroom production. Additionally, if the right composting time is established for the wastes of these crops, the efficiency of the materials in the production of mushroom can be promoted. This work was carried out with an aim to study the effectiveness of selected agro waste substrates for oyster mushroom (P. ostreatus) cultivation in terms of nutritional indices and productivity of the mushroom.

\section{Materials and Methods}

The research was conducted in a Mushroom Cultivation Room (MCR) at Department of Life Sciences, Kristu Jayanti College, Bengaluru, Karnataka. The substrates used for the mushroom cultivation were coconut coir, banana leaves, paddy straw.

\section{Pure culture preparation}

Pure cultures of oyster mushroom were obtained by tissue culture fruiting bodies of oyster mushroom as per the method described by Chih-Ming et al. (14). Mother spawn is the mushroom fungus grown on the grain based medium. In the present study, disease-free sorghum grains were used as substrate for growing mother spawn material as per Chih-Ming et al. (14). Planting spawn is a term used to describe subsequent preparation of spawn from mother spawn culture. The method to raise planting spawn was same as that used for preparation of mother spawn except that instead of glass bottles, polypropylene bags were used as containers for filling the grains.

\section{Substrate preparation and inoculation}

Properly prepared paddy straw produces a better yield of mushrooms. To use paddy straw as a substrate to grow mushroom it needs to be chopped, cleaned and pasteurized before being used as a substrate (15). Banana leaves were cut in small length of at least $10 \mathrm{~cm}$ and made into bundles and were sterilized (16). Coconut coir was prepared and sterilized by cutting the coconut husk manually into small pieces using a knife (17). In separate polythene bags, each substrate was placed as a single layer. $10 \%$ of spawn was spread over it the substrate layer on the outer sides of the bags to facilitate fruiting body formation. Over the spawn, a layer of substrate was overlaid and the process was repeated till $3 / 4^{\text {th }}$ of the bag. Finally the top of the bags was covered with loose straw and pressed in tight. The bags were tightly closed with tying ropes. Holes were punctured aseptically by sharp sterilized pins to ensure adequate $\mathrm{O}_{2}, \mathrm{CO}_{2}$ and gas exchange. After this, bags were moved into MCR for 3 weeks of incubation at 25$27^{\circ} \mathrm{C}$ and monitored daily for possible contamination (18). MCR was cleaned, mopped and disinfected prior to transferring the mushroom bags. The bags were arranged on the wooden shelves in the room with a space of about $10 \mathrm{~cm}$ between the bags (19). Formation of mycelia was monitored regularly by observing the development of white threads through the substrates. On appearance of pin head or initiation of cropping, bags were slit open at the bottom of the neck to enhance flushing. The bags were watered regularly with distilled water using a spray bottle to provide proper humidity (between $70-90 \%$ ) for the growth of the mushroom (20). Oyster mushroom is harvested when the fruiting body becomes curled under edges and well-formed gills. Care was taken to limit damage to immature to remain. The mushroom was removed without damaging the bed. The fruiting bodies when developed, mushrooms were harvested by gentle twisting or with sharp sterilized knife. Mushrooms were plucked before they shed spores to maintain quality (15).

\section{Growth and Yield studies of oyster mushroom}

Total colonization of each type of substrate by the mycelia (spawn running) after the day of spawning within the bags was recorded. The colonization was seen by the formation of white mycelia throughout the substrates within the bags. The time taken for the appearance of pinhead and fruiting body were observed every two days intervals and the number of days it took for first primordial formation was observed and recorded (21). The length of the stalk of the harvested mushroom was measured using the ruler. The length of the stalk was measured from the tip of the stalk to the base of the caps. This was done for each harvest and the average calculated. The perimeter of the caps was measured using a measuring scale and the value recorded. Average was calculated from the data of each harvest (22). The total weight of 
mushrooms harvested from the various substrates was measured using the electronic balance. The weight of the harvested mushrooms at different flushes were also weighed and recorded. The total weight of the harvested mushrooms after cropping was then calculated by simple addition (23). Biological Efficiency (BE) of mushrooms for each substrate were calculated by dividing weight of fresh mushroom yield (in $\mathrm{Kg}$ ) by weight of air dried substrate (in Kg) and multiply by 100 (24).

$$
\mathrm{BE}=\frac{\text { Total weight of fresh mushroom yield }(\mathrm{Kg}) \times 100}{\text { Total dry weight of the substrate }(\mathrm{Kg})}
$$

\section{Nutritional content of harvested mushroom}

\section{Moisture Content}

The moisture content is determined by measuring the weight of a material before \& after the water removed by evaporation. To obtain an accurate measurement of the moisture content of material evaporation method necessary to remove all water molecules. Moisture content was determined by formula mentioned by Sonali (15).

\section{Chemical toxicity test of mushroom}

A drop of juice was pressed out of the fresh fruiting body on a piece of newspaper. After the spot had dried, hydrochloric acid was dropped on it. A blue spot indicates the toxicity of mushroom (24).

\section{Determination of total protein}

Five gram of mushroom was taken with $50 \mathrm{ml}$ phosphate buffer and homogenized with a tissue homogenizer. $5 \mathrm{ml}$ of the homogenized was taken with 50 $\mathrm{ml}$ of $0.1 \mathrm{~N} \mathrm{NaOH}(25)$ and the total protein content was measured according to the method of Lowry et al. (26).

\section{Determination of total lipid}

Total lipid was determined by modified method of Nuhu et al. (25). Five gram of each sample was suspended in $50 \mathrm{ml}$ of chloroform: methanol (2:1) mixture then mixed thoroughly and let stand for 3 days. The solution was filtrated and centrifuged at $1000 \mathrm{~g}$ by a centrifuge machine. The upper layer of methanol was removed by Pasteur pipette and chloroform was evaporated by heating. The remaining was the crude lipid which is weighed on an electronic balance.

\section{Determination of total ash}

One gram of the sample was weighed accurately into a crucible. The crucible was placed and heated first over a low flame till all the material was completely charred, followed by heating in an oven for about 6 hours at $600^{\circ} \mathrm{C}$. It was then cooled and weighed. The total ash was calculated using the formula as mentioned by Nuhu et al. (25).

\section{Determination of crude fiber}

Ten grams of moisture and fat-free sample was taken in a beaker and $200 \mathrm{ml}$ of boiling $0.255 \mathrm{~N} \mathrm{H}_{2} \mathrm{SO}_{4}$ was added. The mixture was boiled for 30 minutes keeping the volume constant by the addition of water at frequent intervals. The mixture was then filtered through a muslin cloth and the residue washed with hot water till free from acid. The material was then transferred to the same beaker, and $200 \mathrm{ml}$ of boiling $0.313 \mathrm{~N} \mathrm{NaOH}$ added. After boiling for 30 minutes (keeping the volume constant as before) the mixture was filtered through a muslin cloth and the residue washed with hot water till free from alkali, followed by washing with some alcohol and ether. It was then transferred to a crucible, dried overnight at $80 \sim 100^{\circ} \mathrm{C}$ and weighed in an electric balance (27).

\section{Determination of available or total carbohydrate}

The content of available carbohydrate (total carbohydrate) was determined by the equation described by Raghuramulu et al. (27).

\section{Determination of metabolizable energy}

The content of availed or carbohydrates can supply energy. The metabolizable energy is determined by the equation described by Sonali (15).

\section{Results and Discussion \\ Pure Culture Preparation}

Pure cultures of Pleurotus ostreatus were obtained on wheat agar medium and the pure cultures were further used in spawn preparation. The purity of the culture was determined by macroscopic and microscopic appearance of the mycelium of the oyster mushroom. Mother spawn was prepared without any contamination

Table 1. Effect of different substrates on the mycelial invasion and formation of fruiting bodies of oyster mushroom

\begin{tabular}{|c|c|c|c|c|}
\hline $\begin{array}{c}\text { Substrate } \\
\text { used }\end{array}$ & $\begin{array}{c}\text { Spawn } \\
\text { running } \\
\text { (Days after } \\
\text { spawning) }\end{array}$ & $\begin{array}{c}\text { Pin head formation (Days } \\
\text { after spawn running) }\end{array}$ & $\begin{array}{c}\text { Fruiting body formation (Days } \\
\text { after spawn running) }\end{array}$ & $\begin{array}{c}\text { Harvesting duration } \\
\text { between flushes (Days } \\
\text { after spawn running) }\end{array}$ \\
\hline Paddy straw & 2 & 11 & 3 & 4 \\
\hline $\begin{array}{c}\text { Banana } \\
\text { leaves }\end{array}$ & 13 & 10 & 3 & 8 \\
\hline Coconut coir & 10 & 12 & 3 & 13 \\
\hline
\end{tabular}


10.5530/ctbp. 2021.3s. 27

Table 2. Effect of different substrates on growth and yield of oyster mushroom

\begin{tabular}{|c|c|c|c|c|c|c|c|c|}
\hline \multirow{2}{*}{ Substrate used } & \multirow{2}{*}{$\begin{array}{l}\text { Length of } \\
\text { the stipe } \\
(\mathrm{cm})\end{array}$} & \multirow{2}{*}{$\begin{array}{l}\text { Pileus } \\
\text { diameter } \\
\text { (cm) }\end{array}$} & \multicolumn{4}{|c|}{ Yield of mushroom (gms) / flushes } & \multirow{2}{*}{$\begin{array}{l}\text { Total } \\
\text { weight } \\
\text { (gms) }\end{array}$} & \multirow{2}{*}{$\begin{array}{l}\text { Biological Efficiency } \\
\text { (BE) }(\%)\end{array}$} \\
\hline & & & $1^{\text {st }}$ & $2^{\text {nd }}$ & $3^{\text {rd }}$ & $4^{\text {th }}$ & & \\
\hline Paddy straw & 4.87 & 11.37 & 132.23 & 186.28 & 263.57 & 174.86 & 756.94 & 75.69 \\
\hline Banana leaves & 5.66 & 10.26 & 377.67 & 300 & 81.51 & No harvest & 759.18 & 75.91 \\
\hline Coconut coir & 9.96 & 9.13 & 270 & 221.50 & 185.40 & No harvest & 676.90 & 67.69 \\
\hline
\end{tabular}

and the entire wheat grains were colonised by the fungal mycelium. The mother spawn was used to prepare planting spawn. The planting spawn preparation was also carried out with healthy grains of wheat in sterilized bags. No contamination was observed indicating purity and non-toxicity of the spawns. Both mother and planting spawns were maintained at $4^{\circ} \mathrm{C}$ till the entire usage.

\section{Growth and Yield parameters of harvested mushroom}

Different agro-wastes viz., Paddy straw, Banana leaves and coconut coir were used as substrates for mushroom cultivation. Various growth factors, yield factors and nutritional indices of the harvested mushroom were recorded and are tabulated in Table 1, 2 and 3. Spawn running was observed in two days in the bags containing paddy straw as the substrate. In the bags packed with banana leaves used as substrates, the spawn running was observed only after 13 days whereas spawn running was recorded after 10 days in bags with coconut fibre as substrate (Fig.1).

Similar results were reported by Eric (20). Our findings were in accordance with the findings of Subhas et al. (23) who reported that banana leaves required least time for mycelium colonization (18.5 days) followed by rice straw (21 days) for the cultivation of oyster mushroom Pleurotus florida. Studies by Margaretta and Ady (17) revealed that bags with coconut coir as substrate were fully filled by mycelium on the 30th day after inoculation. Mycelial growth was influenced by nutrients in the media. White oyster mushroom needs cellulose, lignin, carbohydrates and glucose (28). Belewu and Belewu (16) reported that the mycelia of Volvariella volvaceae covered the banana leaves in about 12 days while full colonization of the substrate was observed in 15 days. In contrast were the results obtained by Govindraju et al. (18) where they observed that the spawn running started from 3rd day for paddy straw, 5th day for banana leaves. Shruti et al. (24) observed spawn running took 2-3 weeks after inoculation in case of wheat straw. The particle sizes of the substrates might influence the mycelia development (29). The fine particle sizes of sole coir influenced the faster mycelia formation. Pinheads formation is the preceding stage of fruiting body formation in mushroom cultivation. In our study as shown in Fig.1, the bags with paddy straw as substrate, small pinheads like structures were observed 11 days after spawn running, In case of banana leaves packed bags, pinhead formations was noted after 10 days whereas pinhead formation was observed after 12 days of spawn running in coconut coir. In the studies of Shruthi et al. (24), pinheads were formed 6-7 days after the spawn running on wheat straw. Ahmad (30) reported complete spawn running in 17-20 days for Pleurotus ostreatus on different substrates and time for pinheads formation was noted as $23-27$ days. Shah et al. (31) reported that primordial formation of $P$. ostreatus appears 27-34 days of inoculation. According to Mondal et al. (32), the presence of right proportion of alpha-cellulose, hemicellulose and lignin is responsible for higher mycelium running rate and growth in banana leaves and rice straw. Optimal $\mathrm{C}$ : $\mathrm{N}$ ratio might be responsible for the higher yield in these substrates. Similar result was found by Chang \& Quimio (33) and Gohl (34). Margaretta and Ady (17) observed that the primordia formation on coconut fibre appeared at 33 days after inoculating. Similarly Erik (20) and Sopit (35) reported primordial formation in coconut residue substrate. The primordia formation was affected by humidity and media substrate (36).In the present study, fruiting body were completely produced 3 days after pinhead formation in all substrates (Fig.1) and the mushrooms were harvested the next day before spore production started (Plate 7). Subhas et al. (23) observed that first fruiting and first harvest of Pleurotus florida was faster in banana leaves (19.5 and 23 days) followed by rice straw (23 and 26.25 days), respectively. Sopit (35) observed that fruiting body formation took 25 days in coconut residue as substrate. Shruti et al. (24) reported that the fruiting bodies appeared 10 days after pinheads formation. Margaretta and Ady (17) reported that the coconut coir media helped the mycelia to attach to the substratum effectively and prevent the fruiting body to shake off easily. It is suspected that coconut coir has a resemble shape to a tree trunk or weathered wood where white oyster mushroom grows as a parasite on the natural habitat. The structure and shape of coconut coir makes it possible to store the water promoting higher yield.

In our study, length of the stipe and diameter of the pileus of the harvested mushrooms varied from substrate to substrate (Table 2). The average length of stipe was found to be highest $(9.96 \mathrm{~cm})$ in coconut coir as substrate followed by banana leaves $(5.66 \mathrm{~cm})$ and 
10.5530/ctbp.2021.3s.27

Table 3. Effect of different substrates on the nutritional content of harvested oyster mushrooms

\begin{tabular}{|c|c|c|c|c|c|c|c|c|}
\hline \multirow{2}{*}{ Substrate used } & \multicolumn{8}{|c|}{ Nutritional indices of the harvested mushroom (gm/100gm) } \\
\cline { 2 - 9 } & $\mathrm{M}(\%)$ & $\mathrm{CT}$ & $\mathrm{P}$ & $\mathrm{L}$ & $\mathrm{A}$ & $\mathrm{CF}$ & $\mathrm{TC}$ & $\mathrm{ME}(\mathrm{Kcal} / 100 \mathrm{gm})$ \\
\hline Paddy straw & 64 & No & 2.8 & 0.6 & 9 & 0.885 & 22.715 & 207.977 \\
\hline Banana leaves & 60 & No & 1.8 & 0.4 & 6 & 0.594 & 31.206 & 274.951 \\
\hline Coconut coir & 68 & No & 3.2 & 1.2 & 12 & 3.388 & 12.222 & 125.287 \\
\hline
\end{tabular}

Key: M: Moisture; CT: Chemical toxicity; P : Protein content; L: Lipid content;

\section{A: Ash content; CF: Crude Fibre; TC: Total Carbohydrate; ME: Metabolizable Energy}

paddy straw as substrate $(4.87 \mathrm{~cm})$. The average pileus diameter was found to be the highest in paddy straw $(11.37 \mathrm{~cm})$ followed by coconut coir bags $(10.26 \mathrm{~cm})$ and banana leaves $(9.13 \mathrm{~cm})$. Large sized mushrooms were obtained in some harvest across different substrates (Plate 8). Our results were in conformity with the findings of Erik (20). Similar results were reported by Subhas et al. (23), where they reported stipe length from first harvest of in banana leaves as $6.76 \mathrm{~cm}$ followed by wheat straw $(6.62 \mathrm{~cm})$. The cap diameter was found highest from wheat straw $(9.87 \mathrm{~cm})$ followed by banana leaves $(9.17 \mathrm{~cm})$, rice straw $(8.96 \mathrm{~cm})$, under similar environment. Margaretta and Ady (17) observed that the growth of fruiting bodies using coconut coir media had an average diameter of $7.96 \mathrm{~cm}$ and weight of $120.62 \mathrm{~g}$ each colonize bag at once harvesting. The type of agricultural wastes and the treatment methods in preparing the compost may be responsible for change in the stipe length, pileus width and overall yield of the mushrooms grown in the different farm substrates. In addition, major ecological factors such as temperature, humidity, fresh air and compact material can also influence stalk height, stalk diameter and cap size in mushroom.

In the present study, four flushes were obtained from paddy straw whereas only three flushes could be observed in banana leaves and coconut coir as substrate although the total yield didn't vary considerably (Table 2). Ramzan et al. (37) obtained 3-5 flushes from wheat and paddy straw. Bhatti et al. (38) got 4-6 flushes from different substrates. Harvesting duration between flushes varied for each substrate where it was 4 days for paddy straw, 8 days for banana leaves and 13 days for coconut coir. Govindraju et al. (18) reported that the less harvesting period, high flush height and bud formation were observed in Paddy straw. Their data also displayed that the minimum period on an average basis between flushes was taken on paddy straw which was 4-6 days in $P$. ostreatus as observed in the present study.

The yield of mushroom in different substrates varied with every flush (Table 2). Bags with paddy straw exhibited increase in mushroom yield from first harvest to third flush with decline in mushroom yield in the fourth flush. In contrast, the yield of mushroom decreased with every flush in bags with banana leaves and coconut coir as substrate. The total yield of mushroom was highest in banana leaves $(759.18 \mathrm{gm})$ slightly more than paddy straw $(756.94 \mathrm{gm})$ followed by coconut coir $(676.90 \mathrm{gm})$.
Our findings (Table 2) are in conformity with the findings of Subhas et al. (23) who reported that higher yield from first harvest was obtained from banana leaves $(530 \mathrm{gm})$ followed by rice straw (463.8 gm). The authors also studied that highest final mean yield was obtained by banana leaves $(1190 \mathrm{gm})$ followed by rice straw $(973.8$ $\mathrm{gm})$. According to Mamiro and Mamiro (39) the reason for higher yield from banana leaves rather than rice straw may be due to the high water holding capacity of banana leaves. Sharma et al. (28) cultivated P. ostreatus on combination of different substrates such as rice straw, rice straw + wheat, etc and observed that rice straw was found as a best substrate with yield (381.85 gm). Erik (20) also reported high yield of $P$.ostreatus with coconut coir.

Biological efficiency of the substrates (Table 2) was found to be above $75 \%$ with only slight variation between that of banana leaves $(75.91 \%)$ and paddy straw $(75.69 \%)$. BE for coconut coir was also good $(67.69 \%)$. This suggests that the substrate which is used more by enzymatic activity of fungus gives more yields (23). Thomas et al. (40) soaked coconut coir for 16 hours for the growth of oyster mushroom and still had good results.in their study, biological efficiency of $39.7 \%$ was obtained in coir pith. Sharma et al. (28) reported highest yield and biological efficiency of the oyster mushroom from rice straw. Satisfactory results were obtained by Sturion (41) using substrates based on banana leaves straw reaching $93 \%$ of productivity.

\section{Nutritional indices of harvested mushroom}

No chemical toxicity (Table 3 ) was observed in the harvested mushrooms on any substrates indicated by the absence of blue spots on reacting with $\mathrm{HCl}$ on lignin containing paper, revealing the presence of non-toxic compounds, thus indicating the harvested mushrooms to be edible (Plate 9). Similar studies have been carried out by Shruti et al. (24). The moisture contents of oyster mushroom harvested on various substrates was found to be highest in coconut coir $(68 \%)$ followed by paddy straw $(64 \%)$ and banana leaves $(60 \%)$. The protein content and the lipid content of the mushroom was found to be highest from coconut coir $(3.2 \mathrm{gm} / 100 \mathrm{gm}$ and $1.2 \mathrm{gm} / 100 \mathrm{gm}$ respectively) followed by Paddy straw and Banana leaves. Similarly ash content and crude fibre was also highest for coconut coir (12gm/100gm and $11 \mathrm{gm} / 100 \mathrm{gm}$ respectively) followed by the paddy straw and banana leaves. Interestingly, 
total carbohydrate and metabolizable energy (available carbohydrate) was estimated to be maximum for banana leaves $(31.206 \mathrm{gm} / 100 \mathrm{gm}$ and $274.951 \mathrm{Kcal} / 100 \mathrm{gm}$ respectively) followed by paddy straw and coconut coir (Table 3). Nuhu et al. (25) reported nutritional content of various oyster mushroom species. They reported that $P$. ostreatus had $86 \%$ moisture, $3 \sim 3.8 \mathrm{~g}$ of proteins, $0.63 \sim 0.73 \mathrm{~g}$ of lipids, 3.2 $3.6 \mathrm{~g}$ of fiber and $5.0 \sim 5.4 \mathrm{~g}$ of carbohydrates. The total ash content found in Pleurotus ostreatus was 1.1 1.3 g. Watanabe et al. (42) found the carbohydrate value as $47.9 \mathrm{~g}$ in $100 \mathrm{~g}$ dry matter. Adedokun and George-David (43) also estimated nutritional content of Pleurotus floridanus grown on various agricultural wastes. Very few reports have been found that evaluate the nutritive value of mushroom grow on coconut coir. From this study, it can be inferred that the chemical composition of edible mushrooms determines their nutritional value and sensory properties. They differ according to species but this difference also depends on the substratum and atmospheric conditions. The findings of Silva et al. (44) and Khan et al. (45) also indicate that the nutritional composition of oyster mushroom differs significantly when grown in different substrates, but chemical composition of mushroom does not correspond to the chemical composition of substrate.

\section{Conclusion}

In the present study, Oyster mushrooms $(P$. ostreatus) were grown on different substrates viz., Paddy straw, banana leaves and coconut coir. Growth and yield studies were undertaken and harvested mushrooms were also studied for their nutritional indices. Biological efficiency of the substrate was also determined. It was observed that all the three substrates were efficient as substrate for mushroom cultivation. Mushrooms have high content of protein, edible fiber and minerals and low lipid content. Results of the present study also indicated that the studied mushrooms have good nutritive value for human although the nutritional content varied with each substrate. Cultivation of oyster mushrooms is simple and requires low cost, giving consistent growth with high biological efficiency. Protein is important nutritional component and protein deficiency is the world's most serious human nutritional problem, especially in third world countries. So mushroom is a promising food that may overcome protein energy malnutrition problem in the third world. The results of the present study should be taken as a measure to utilize wastes for use in mushroom production but also to indicate the way to contribute to reducing solid waste disposal problems. The study can also pave way for agribusiness to examine these residues as valuable resources and develop new enterprises to use them to produce nutritious mushroom products and help to dispose the agro-wastes in an environment friendly manner. In addition the present study can be further studied to examine the spent substrate and its use as cattle feed, fertilizer or landfills. In the present study, cultivated mushrooms were not only found to be normal but also non-toxic. The present study can be a base to develop an approach that integrates biotechnology with environmental waste management to achieve zero waste from industries. Therefore cultivation of oyster mushroom on agricultural wastes provides multidisciplinary advantages for human being, animals as well as for the ecosystem.

\section{References}

1. Chang, S.T. (2007). Training manual on mushroom cultivation technology, UNAPCAEM

2. Cohen, R., Persky, L., Hadar, Y. (2002). Biotechnological application and potential of wooddegrading mushrooms of the genus Pleurotus. Appl. Microbio Biotechnol., 58: 582-594.

3. Dike, K.S., Amuneke, E.H., Ogbulie, J.N. (2011). Cultivation of Pleurotus ostreatus: an edible mushroom from agro base waste products, J. Microbiol. Biotech., 1 (3):1-14.

4. Kong, W.S. (2004). Description of Commercially Important Pleurotus Species. In: Choi, K.W., Ed., Mushroom Growers' Handbook 1: Oyster Mushroom Cultivation, MushWorld, Seoul, 54-61.

5. Suman, B.C., Sharma, V.P. (2007). Mushroom cultivation in India. Daya Publishing House, Delhi.

6. Mdconline (2013). Oyster mushroom, Missouri Department of Conservation.

7. Rangel, J.I., Leal, H., Palacios-Mayorga, S., Sánchez, S., Ramirez, R., Méndez-García, T. (2006). Coconut fiber as casing material for mushroom production, TERRA Latino americana, 24 (2): $207-213$.

8. Kwon, H., Kim, S.B. (2004). Oyster mushroom cultivation. In: Mushroom Growers' Handbook, pp $139-152$.

9. Howard, R.L., Abotsi, E., Jansen van Rensburg E. L., Howard S. (2003). Lignocellulose biotechnology: issues of bioconversion and enzyme production, African Journal of Biotechnology, 2 (12): 602 - 619.

10. Poppe, J. (2004). Agricultural wastes as substrates for oyster mushroom. In: Mushroom Growers Handbook. p. 80-99.

11. Meerow, A.W. (1994). Growth of two subtropical ornamentals using coir (coconut mesocarp pith) as a peat substitute, Hort. Science, 29 (12): 1484 $-1486$.

12. Amuneke, E.H., Dike, K.S., Ogbulie, J.N. (2011). 
10.5530/ctbp. 2021.3s. 27

Cultivation of Pleurotus ostreatus: An edible mushroom from agro base waste products. J. Microbiol. Biotech. Res., 1 (3): 1-14.

13. Horn, N. L. (2004). Promotion of mushroom production and consumption in northern, Directorate of Agricultural Research and Training (Plant Production Research).

14. Chih-Ming, H., Khalid, H., Van, T.C., Hui-Ling, L. (2018). Isolation of Mother Cultures and Preparation of Spawn for Oyster Mushroom Cultivation Department of Soil and Water Sciences, UF/IFAS Extension.

15. Sonali, D.R. (2012). Cultivation and study of growth of oyster mushroom on different agricultural waste substrate and its nutrient analysis. Advances in Applied Science Research, 3 (4):1938-1949.

16. Belewu, M.A., Belewu, K.Y. (2005). Cultivation of mushroom (Volvariella volvacea) on banana leaves. African Journal of Biotechnology, 4(12): 1401-1403.

17. Margaretta, C., Ady Suryawan, (2018). Economical and ecological friendly of growth media for edible mushroom Pleurotus ostreatus made of the coconut waste. Jurnal Biologi Udayana, 22(1):35-41.

18. Govindaraju, S., Sangeetha, S., Indra Arulselvi, P. (2013). Effect of different agro-wastes on mass production of edible mushroom Pleurotus ostreatus. Indian Journal of Applied Research, 3(6): 33-35.

19. Chenjerayi, K., Edna, K., Audrey, M., Tsungai, C., Arnold, M., Vimbai, M. (2004) Manual For Mushroom Cultivation In Mushroom Production Manual. Edited by Professor C. J. Chetsanga. Biotechnology Trust of Zimbabwe.

20. Eric, O.M. (2015). Comparative studies on growth and yield of Pleurotus ostreatus on different types of substrates. M.Sc Biotechnology thesis to the Department of biochemistry and biotechnology, College of Science, Kwame Nkrumah University of Science and Technology, Kumasi, Ghana.

21. Chandra, P.P. (2006). Cultivation of oyster mushroom: A sustainable approach of rural development in Nepal. Journal of Institute of Science and Technology, 21(1):56-60.

22. Buah, J.N., Van der Puije, G.C., Bediako, E. A., Abole, E.A., Showemimo F. (2010). The growth and yield performance of oyster mushroom (Pleurotus ostreatus) on different substrate. Biotechnology, 9(3):338-342.
23. Subhas, N., Viwek, T., Bikram, B., Praksah, P., Bhanu, B. G., Laxman, A. (2018). Performance of different substrates on the production of Oyster mushroom (Pleurotus florida) at Gokuleshwor, Darchula. International Journal of Scientific and Research Publications, 8(6): 231-240.

24. Shruti, P., Nivedita, S., Dharmesh, G. (2017). A Study on Cultivation and Yield Performance of Oyster Mushroom (Pleurotus ostreatus) on Wheat Straw Mixed with Horticultural Waste (Apple Pomace) in Different Ratio and their Nutritional Evaluation. Int. J. Curr. Microbiol. App. Sci., 6(8): 2940-2953.

25. Nuhu, A., Ruhul, A., Asaduzzaman, K., Ismot, A., Mi Ja, S., Min Woong, L., Tae Soo, L. (2008). Nutritional Analysis of Cultivated Mushrooms in Bangladesh Pleurotus ostreatus, Pleurotus sajor-caju, Pleurotus florida and Calocybe indica. Mycobiology, 36(4): 228-232.

26. Lowry, H., Rosebrough, N.J., Farr, A.L., Randall, R. J. (1951). Protein measurement with the Folin phenol reagent. J. Biol. Chem., 193(1):265-75.

27. Raghuramulu, N., Madhavan, N.K., Kalyanasundaram, S. (2003). AManual of Laboratory Techniques, National Institute of Nutrition. Indian Council of Medical Research, Hyderabad, India, pp. 56-58.

28. Sharma, S., Kailash, P., Yadav, R., Chandra,P., Pokhrel, P. (2013). Growth and yield of oyster mushroom (Pleurotus ostreatus) on different substrates. J. New Biolog. Rep., 2(1): 03-08.

29. Verma, L.S., Marschner, P. (2013). Compost effects on microbial biomass and soil $P$ pools as affected by particle size and soil properties, Journal of Soil Science and Plant Nutrition, 13 (2): 313 - 328.

30. Ahmad, I.(1986). Some studies on oyster mushroom (Pleurotus spp.) on waste material of corn industry. M.Sc thesis. Department of plant pathology, Faisalabad.

31. Shah, Z.A., Ashraf, M., Ishtiaq M.C. (2004). Comparative study and cultivation and yield performance of oyster mushroom (Pleurotus ostreatus) on different substrates (wheat straw, leaves, sawdust). Pakistan Journal of Nutrition, 3(3): $158-160$.

32. Mondal, S.R., Rehana, M.J., Noman, M.S., Adhikary, S.K. (2010). Comparative study on growth and yield performance of oyster mushroom (Pleurotus florida) on different substrates. J. Bangladesh Agril. Univ., 8(2): 213-220. 
33. Chang, S.T., Quimio, T.H. (Eds.). (1982). Tropical mushrooms: biological nature and cultivation methods. Chinese University Press, Hongkong.

34. Gohl, G. (1993). Tropical Feeds:Feed information and nutritive values. Published by Food and Agriculture Organization of United Nation, Rome.

35. Sopit, V. (2007). The Feasibility of using coconut residue as a substrate for oyster mushroom cultivation. Biotechnology, 6(4):578-582.

36. Alemu, F. 2014. Cultivation of Pleurotus ostreatus on Grevillea robusta leaves at Dilla University, Ethiopia. J. of Yeast and Fungal Research, 5(99):74-83.

37. Ramzan, M. (1982). Studies on the cultivation of oyster mushroom (Pleurotus spp) in Faisalabad M.Sc., thesis, department pathology, Faculty of Agriculture, University of Agriculture, Faisalabad, Pakistan.

38. Bhatti, M.A. (1984). Mushrooms as commercial crop. Progressive farming, 4: 5-10.

39. Mamiro, D.P., Mamiro, P.S. (2011). Yield and mushroom size of Pleurotus ostreatus grown on rice straw basal substrate mixed and supplemented with various crop residues. Journal of Animal \& Plant Sciences, 10 (1): 1211-1218.

40. Thomas, G.V., Palaniswami, C., Prabhu, S.R.,
Gopal, M., Gupta, A. (2012). Cocomposting of coconut coir pith with solid poultry manure. Current Science, 104 (2): $245-250$.

41. Sturion, G.L. (1994). Utilização da folha da bananeira como substrato para o cultivo cogumelo (Pleurotus spp.). M.Sc. Dissertation. Escola Superior de Agricultura. USP.

42. Watanabe, T., Tsuehihasi, N., Takai, Y., Tanaka, K., Suziki, A. (1994). Effects of ozone exposure during cultivation of oyster mushroom (Pleurotus ostreatus) on chemical components of the fruit bodies. J. Jpn. Soc. Food Sci. Technol., 41: 705-708.

43. Adedokun, O.M., George-David, M. (2016). Nutritional profile and yield of Oyster mushroom cultivated on selected agricultural wastes. African Crop Science Journal, 24(3): 259 - 265.

44. Silva, S.O., Gomes da Costa, S.M., Clemente, E. (2002). Chemical composition of Pleurotus pulmonarius (Fr.) Quel., substrates and residue after cultivation. Brazilian Archives of Biology and Technology, 45(4): 531-535.

45. Khan, A. Md., Tania, M., Ruhul Amin, S.M., Nadia Alam, Nazim U. Md. (2008). An investigation on the nutritional composition of mushroom (Pleurotus florida) cultivated on different substrates. Bangladesh Journal on Mushroom, 2(2):17-23. 